UCRL-ID-126123

\title{
Separable High Explosive Systems
}

\author{
M. Finger \\ P. Archibald
}

\section{DISCLAIMER}

\begin{abstract}
This report was prepared as an account of work sponsored by an agency of the United States Government. Neither the United States Government nor any agency thereof, nor any of their employees, makes any warranty, express or implied, or assumes any legal liability or responsibility for the accuracy, completeness, or usefulness of any information, apparatus, product, or process disclosed, or represents that its use would not infringe privately owned rights. Reference herein to any specific commercial product, process, or service by trade name, trademark, manufacturer, or otherwise does not necessarily constitute or imply its endorsement, recommendation, or favoring by the United States Government or any agency thereof. The views and opinions of authors expressed herein do not necessarily state or reflect those of the United States Government or any agency thereof.
\end{abstract}

\section{RECEIVED}

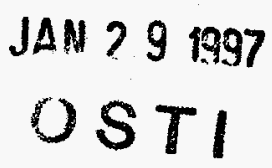

October 27, 1971

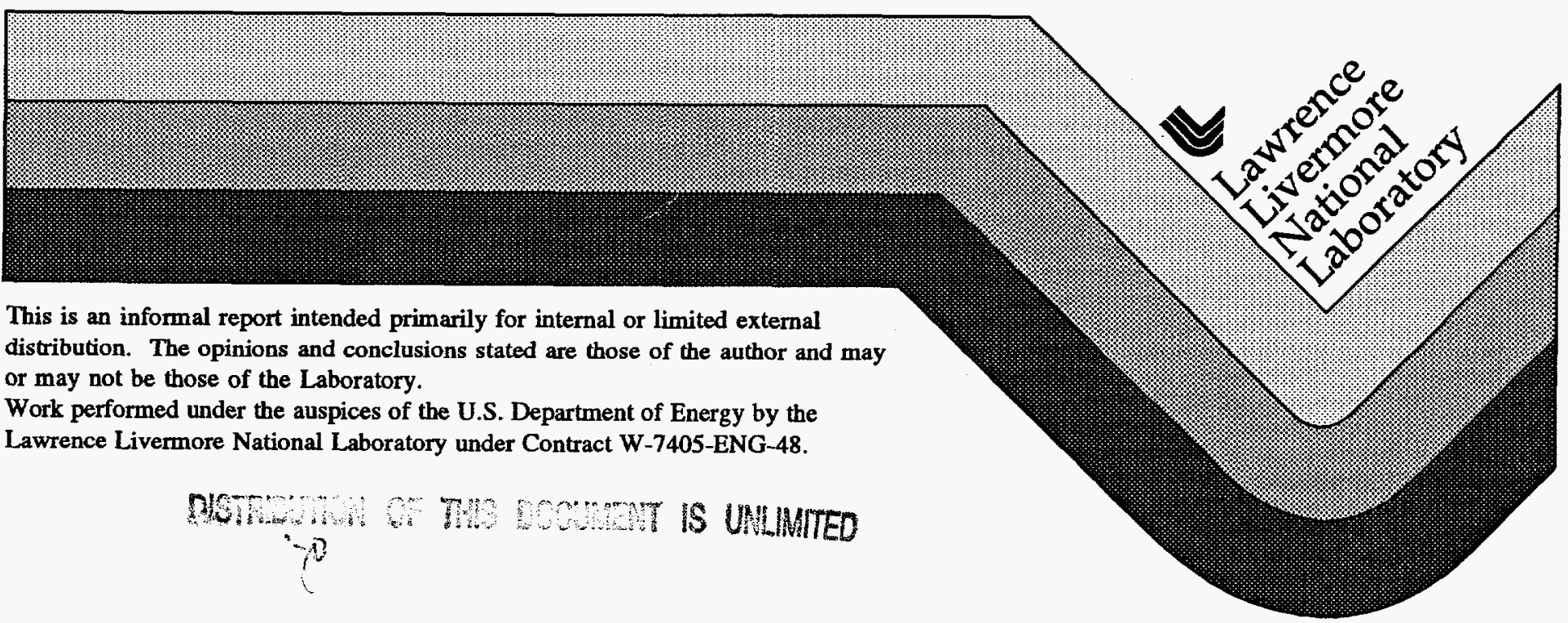




\section{DISCLAMMER}

Portions of this document may be illegible in electronic image products. Images are produced from the best available original document. 
L. M. McGrew

COCCA $71-75$

Page No. 2 of 4

October 27, 1971

1.I Two Component: Liquid-Liquid

Liquid mixtures should behave ä̉s a homogeneous explosive and give predictible explosive performance. The individual components may, in themselves, be non-explosives. Mixtures of non-explosives, however, may be extremely sensitive. A system that mixes and forms the explosive seconds before detonation could then conceivably use an extremely shock sensitive explosive. Liquids, in general, suffer from lower energy than PBX's and have possible toxicity problems. However, it may be possible to use a wide variety of chemical systems, including some possible cryogenic explosives.

1.2 Two Component: Solid-Liquid

The solid component could be either the oxidizer or fuel component. In this system, the solid could be pressed to the desired density or formed to a porous structure and the Iiquid fuel would be injected. Some of the mixtures are very shock sensitive, i.e. Lithium Perchlorate/hydrazine; and they might be used in detonators. These mixtures are heterogeneous and their detonation properties are unknown. A few systems may have energies at the IX-04 to 9404 level. Generally, however, practical systems appear to be in the Composition B to IX-04 energy class.

1.3 Three Component

Any combination of oxidizers and fuels is possible and may lead to slightly greater energy or other desirable properties. However, the main purpose of this system is to make use of the strength of a metal fuel or solid oxidizer to provide structural support. The metal or oxidizer could be in the form of a honeycomb structure.

2. Wooden Explosive

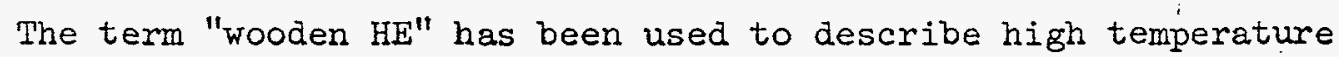
stable explosives. In our context, we refer to a very insensitive explosive. An explosive, that by standard tests, will not detonate. The goncept is to convert this wooden material into an explosive just before its intended use. Two examples of systems that might be made tow work in this concept are: 
L. M. McGrew

2.1 A composite Propellant

This material may not be detonable under any reasonable criteria. However, by an extremely strong shock of long duration, or by adding thermal energy, the material may be made to detonate. Perhaps multiple shocks are necessary to detonate.

2.2 Perchlorate/Graphite

The system $\mathrm{KClO}_{4} /$ Graphite cannot be detonated by conventional means. Based on a suggestion by $E$. Lee, it may be possible to quickly heat the graphite electrically and cause a detonation. This system may also yield the combined thermal and chemical energy.

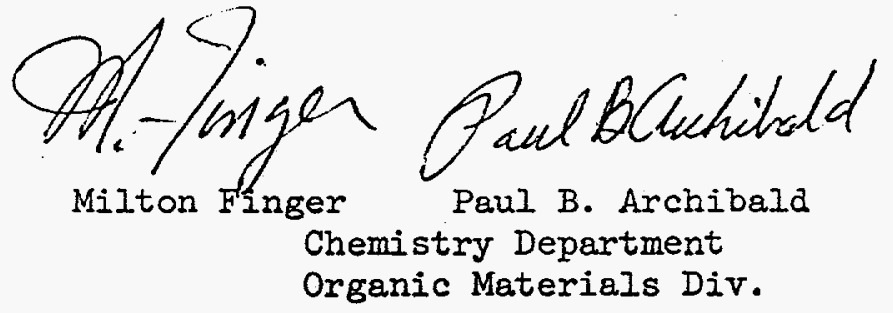

MF : eg

Distribution:

I. M. MaGrew

$1 / 10 \mathrm{~A}$

J. Kury

$2 / 10 \mathrm{~A}$

A. Todaro

$3 / 10 \mathrm{~A}$

P. Archibala

4/10 A

M. Finger

5/10 A

E. Bissell

$6 / 10 \mathrm{~A}$

E. James

$7 / 10 \mathrm{~A}$

L. Green

$8 / 10 \mathrm{~A}$

K. Scribner

9/10 A

M. Finger/File 60.I

$10 / 10 \mathrm{~A}$

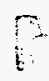

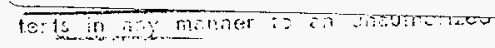


TABLE I. SEPARABLE EXPLOSIVE SYSTEMS

\begin{tabular}{|c|c|c|c|c|c|c|c|}
\hline System & Example & $\begin{array}{l}\text { Significant } \\
\text { Advantages }\end{array}$ & Problems & Unknowns & Energy & $\begin{array}{c}\text { Density } \\
\text { g/cc }\end{array}$ & Sensitivity \\
\hline \multirow[t]{2}{*}{$\frac{\text { Two Component }}{\text { Liquid-Liquid }}$} & $\operatorname{TNM}^{(1)} / \mathrm{NB}$ & $\begin{array}{l}\text { Non-HE } \\
\text { Components }\end{array}$ & $\begin{array}{l}\text { Toxicity, } \\
\text { Mixing }\end{array}$ & $\begin{array}{l}\text { Freezing } \\
\text { Point }\end{array}$ & $\begin{array}{l}66 \% \text { HMX or } \\
73 \% \text { LX-04 }\end{array}$ & & $\begin{array}{l}\text { Mixture } \\
\text { extremely } \\
\text { sensitive }\end{array}$ \\
\hline & $\mathrm{OF}_{2} / \mathrm{CH}_{2}$ & Energy & $\mathrm{OF}_{2} \begin{array}{c}\text { pressur- } \\
\text { ized }\end{array}$ & $\begin{array}{l}\text { Reactivity, } \\
\text { Handling }\end{array}$ & $=9404$ & & Unknown \\
\hline \multirow[t]{3}{*}{$\begin{array}{l}\text { Solid-Liquid } \\
\text { Solid Oxid }+ \\
\text { Liquid Fuel }\end{array}$} & $\mathrm{LiClO}_{4} / \mathrm{N}_{2} \mathrm{H}_{4}$ & $\begin{array}{l}\text { Non-HE } \\
\text { Components }\end{array}$ & $\begin{array}{l}\text { Toxicity, } \\
\text { Hydroscop- } \\
\text { icity }\end{array}$ & $\begin{array}{r}\text { Detonation } \\
\text { behavior, } \\
\text { Reactivity }\end{array}$ & $>66 \% \mathrm{HMX}$ & 2.75 & $\begin{array}{l}\text { Mixture very } \\
\text { sensitive }\end{array}$ \\
\hline & $\mathrm{NH}_{4} \mathrm{ClO}_{4} / \mathrm{CH}_{2}$ & $\begin{array}{l}\text { Very Insensi- } \\
\text { tive } \mathrm{HE}\end{array}$ & Fabrication & $\begin{array}{c}\text { Detonation } \\
\text { behavior }\end{array}$ & $\sim 80 \%$ of $\mathrm{HMX}$ & 2.78 & Unknown \\
\hline & $\mathrm{NH}_{4} \subset \mathrm{ClO}_{4} / \mathrm{NB}$ & $\begin{array}{l}\text { Very Insensi- } \\
\text { tive } \mathrm{HE}\end{array}$ & & $\begin{array}{l}\text { Detonation } \\
\text { behavior }\end{array}$ & $\sim 84 \%$ of $\mathrm{HMX}$ & 1.76 & Unknown \\
\hline $\begin{array}{l}\text { Solid-Fuel } \\
\text { Liquid Oxid }\end{array}$ & TNM/Anthracene & No $\mathrm{HE}$ & Toxicity & $\begin{array}{l}\text { Detonation } \\
\text { behavior }\end{array}$ & $\sim 70 \%$ HIMX & & Unknown \\
\hline \multirow[t]{2}{*}{$\frac{\text { Three Component }}{\text { Solid-Fuel }}$} & $\mathrm{TNM} / \mathrm{NB} / \mathrm{Al}$ & Strong Structure & Toxicity & $\begin{array}{c}\text { Detonation } \\
\text { behavior }\end{array}$ & $?$ & $?$ & Unknown " \\
\hline & $\begin{array}{r}\mathrm{TNM} / \mathrm{NB} / \mathrm{NH}_{4} \mathrm{ClO}_{4} \\
\quad\end{array}$ & $\begin{array}{l}\text { Strong Structure } \\
\text { Separable but } \\
\text { detonable } \\
\text { liquid }\end{array}$ & Toxicity & $\begin{array}{l}\text { Detonation } \\
\text { behavior }\end{array}$ & 8 & $?$ & $?$ \\
\hline
\end{tabular}

(1) Other liquid Oxidizers include $\mathrm{N}_{2} \mathrm{O}_{4}, \mathrm{HNO}_{3}$, etc. 